\title{
PELATIHAN DAN PEMBIMBINGAN PENULISAN KARYA ILMIAH PENELITIAN TINDAKAN KELAS PADA GURU TK DI WILAYAH LOMBOK
}

\author{
Nurdin \\ UT UPBJJ Mataram \\ Email: nurdin@ut.ac.id
}

\begin{abstract}
Abstrak. IGTKI NTB berada di bawah IGTKI Nasional yang berkedudukan di ibukota negara. IGTKI NTB kepengurusannya berada di ibukota provinsi NTB. TK di provinsi Nusa Tenggara Barat sebanyak 2.317 sekolah yang terdiri dari 147 TK negeri dan 2.170 TK swasta. Guru TK se Provinsi NTB sebanyak 7.700 orang, yang belum berkualifikasi S1 sebanyak 3.200 orang dan yang sudah S1 sebanyak 4.500 orang. Dari jumlah guru yang sudah S1 sebanyak 167 orang telah tercatat menerima tunjangan profesi pendidik. IGTKI beranggotakan TK dan KB sebanyak 7.700 guru yang tersebar di seluruh wilayah NTB. Guru TK dan KB di NTB berkualifikasi beragam, ada lulusan SMP, SMA sederajat, Diploma dan Sarjana. Peningkatan kualifikasi guru lulusan SMP merupakan tanggung jawab direktorat kesetaraan. Sedangkan peningkatan kualifikasi yang lulusan SMA sederajat dan diploma merupakan tanggung jawab kementrian berkerjasama dengan Pemda setempat. Sementara mereka yang sudah berkualifikasi sarjana, dianggap sudah tidak perlu ditingkatkan lagi karena kualifikasinya sudah memenuhi syarat dalam undang-undang Sistem Pendidikan Nasional Nomor 20 tahun 2003.
\end{abstract}

Kata Kunci: Pelatihan Dan Pembimbingan Penulisan Karya Ilmiah, Penelitian Tindakan

\section{PENDAHULUAN}

Analisis dan kondisi mitra yang meliputi demografi, potensi dan permasalahan mitra.

\section{Demografi}

Ikatan Guru Taman Kanak-kanak Indonesia (IGTKI) wilayah Nusa Tenggara Barat merupakan organisasi yang membawahi guru-guru Taman Kanak-kanak di Provinsi Nusa Tenggara Barat. Organisasi IGTK ini berada di bawah IGTKI Nasional yang berkedudukan di Ibukota Negara, yaitu di Jakarta. IGTKI wilayah, terdapat diseluruh Indonesia dan kepengurusannya berada di Ibukota tiap Provinsi. Demikian juga dengan IGTKI Wilayah NTB, kepengurusannya berada di Ibukota Provinsi NTB, yaitu di Mataram. Organisasi ini membawahi IGTKI Cabang yang berada di Kabupaten/Kota. Setiap IGTKI cabang membawahi IGTKI tingkat Kecamatan.

Jumlah Lembaga TK di Provinsi Nusa Tenggara Barat sebanyak 2.317 sekolah yang terdiri dari 147 TK Negeri dan sisanya sebanyak 2.170 swasta. Sedangkan jumlah guru TK se Provinsi NTB sebanyak 7.700 orang. Jumlah ini yang belum berkualifikasi S1 sebanyak 3.200 orang dan yang sudah S1 sebanyak 4.500 orang. Dari jumlah guru yang sudah S1sebanyak 167 orang telah tercatat menerima tunjangan profei pendidik.

\section{Potensi}

Anggota IGTKI adalah guru-guru TK dan Kelompok Bermain baik TK Negeri maupun TK swasta. Dalam hal ini, jumlah anggota IGTKI NTB sekitar7.700 guru yang tersebar di seluruh wilayah NTB. Pada saat ini jumlah guru TK di NTB memiliki kualifikasi yang beragam, mulai dari lulusan SMP, SMA sederajat, Diploma dan Sarjana. Peningkatan kualifikasi guru lulusan SMP merupakan tanggung jawab direktorat kesetaraan. Sedangkan peningkatan kualifikasi yang lulusan SMA sederajat dan diploma merupakan tanggung jawab kementrian berkerjasama dengan Pemda setempat. Sementara mereka yang sudah berkualifikasi sarjana, dianggap sudah tidak perlu ditingkatkan lagi karena kualifikasinya sudah memenuhi syarat dalam undang-undang Sistem Pendidikan Nasional Nomor 20 tahun 2003.

3. Permasalahan

Beberapa permasalahan yang dihadapi oleh IGTKI NTB dan anggotanya adalag sebagai berikut.

a. Para guru TK yang sudah berkualifikasi Sarjana di NTB masih kurang. Meskipun demikian, banyak dari mereka yang 
kualifikasi sarjananya bukan Sarjana PGPAUD/PGTK. Sesuai Peraturan Menteri Pendidikan Nasional (Permendiknas) No 146 ytahun 2014, seharusnya guru-guru PAUD (termasuk TK) harus berkualifikasi S1 PAUD, Psikologi maupun Bimbingan Konseling. Dengan demikian masalah yang dihadapi adalah bagaimana meningkatkan kualifikasi guru TK lulusan SMA dan Diploma menjadi S1?

b. Para guru TK yang memiliki kualifikasi sarjana dan pengalaman mengajar lebih dari 15 tahun, pada umumnya sudah berumur di atas 50 tahun sehingga mereka merasa kesulitan jika harus melakukan penelitian mandiri tanpa bimbingan. Oleh karenanya, masalah yang muncul disini adalah bagaimana para guru TK melakukan penelitian sesuai dengan profesinya sebagai guru TK?

c. Para guru TK yang berkualifikasi S1, banyak yang sudah mencapai pangkat dan Golongan IV dengan masa kerja lebih dari 15 tahun. Mereka yang berada pada kelompok ini, mengalami hambatan untuk naik pangkat lagi karena mereka tidak memiliki karya tulis ilmiah yang merupakan persyaratan untuk bisa naik pangkat dan golongan. Masalah yang bisa dirumuskan adalah: Bagaimana meningkatkan kemampuan guru TK dalam menyusun karya tulis ilmiah sesuai bidang ke TK/PAUD an?

d. Para guru TK yang memiliki kualifikasi sarjana dan memiliki masa kerja di atas 15 tahun rata-rata sudah menjadi guru senior atau sudah menjadi kepala TK, sehingga jika ingin naik jabatan yang paling tep[at adalah menjadi kepala TK atau pengawas TK atau Penilik PAUD.

Sementara untuk menduduki jabatan tersebut, mereka harus memiliki kemampuan dalam menulis karya ilmiah dan memiliki minimal satu karya tulis ilmiah (bisa berupa laporan dan atau artikel ilmiah) baik yang sudah dipublikasi ataupun belum. Masalah yang bisa dirumuskan adalah bagaimana melatig Guru TK agar memiliki kemampuan menyusun karya ilmia berupa laporan atau artikel dengan baik?
Berdasarkan beberapa permasalahan yang sudah disebutkan tersebut, masalah yang disepakati oleh mitra untuk diatasi adalah banyaknya guru-guru TK yang sudah berkualifikasi sarjana dan memiliki pangkat/golongan IV/a namun tidak bisa naik pangkat lagi karena mereka tidak memiliki karya ilmiah dan mereka tidak memiliki kemampuan untuk menyusun karya ilmiahnya sendiri. Jumlah guru TK yang berada pada posisi ini cukup banyak (sekitar $40 \%$ dari jumlah Guru TK se NTB). Oleh karenanya IGTKI berharap ada lembaga yang bisa membantu mereka meningkatkan kemampuan guru-guru TK ini dalam melakukan penelitian khususnya penelitian tindakan kelas dan menyusun karya tulis ilmiah yang bisa mereka ajukan untuk kenaikan pangkat mereka.

Berdasarkan permasalahan yang disampaikan oleh Ketua IGTKI Provinsi Nusa Tenggara Barat tersebut maka kami para dosen di UT Mataram tergerak untuk membantu para guru TK (anggota IGTKI) yang mengalami kesulitan dalam melakukan penelitian dan menyusun karya tulis ilmiah sesuai dengan bidang mereka. Karya tulis ilmiah yang paling tepat untuk guru-guru adalah Penelitian Tindakan Kelas. Pertimbangan kami untuk melakukan kegiatan pengabdian masyarakat berupa pelatihan pelaksanaan dan penyusunan laporan penelitian Tindakan Kelas tersebut adalah:

1. Sebagai Dosen, kami sudah terbiasa membimbing mahasiswa dalam merencanakan, melakukan dan menyusun laporan penelitian (karya tulis ilmiah) khususnya Penelitian Tindakan Kelas.

2. Mitra membutuhkan bimbingan dalam merencanakan, melaksanakan dan menyusun laporan penelitian dan menuliskan artikel ilmiah yang sesuai dengan profesi dan pengalamannya dalam mengajar di lembaga PAUD (TK).

3. Mitra berharap, proses pembimbingan dilakukan secara bertahap dan intensif, mulai

4. dari tahap menentukan judul penelitian, menyusun rencana penelitian, menyusun 
5. intrumen dan alat pengumpul data, melaksanakan penelitian dan pengumpulan data hingga menyusun laporan penelitian dan menyusun artikel ilmiah.

\section{SOLUSI, TARGET, DAN LUARAN KEGIATAN}

A. Solusi

Berdasarkan permasalahan yang muncul dan pertimbangan yang telah dilakukan maka solusi yang dapat diambil adalah memberikan pelatihan dan bimbingan dalam melakukan penelitian tindakan kelas hingga menyususn laporan penelitian dan artikel ilmiah dengan baik. Proses pembimbingan akan dilakukan secara bertahap dan intensif secara individual.

B. Target

Target yang hendak dicapai adalah para guru TK yang menjadi peserta dalam pelatihan ini dapat merencanakan dan melakukan PTK, Menyusun Laporan PTK sesuai dengan kaidah PTK dan menyusun artikel ilmiah berdasarkan laporan PTK yang telah dibuatnya.

C. Luaran Kegiatan

Luaran yang diharapkan dari kegiatan pengabdian kepada masyarakat ini berupa satu laporan penelitian tindakan kelas dari tiap peserta dan satu artikel ilmiah dari tiap peserta, Laporan Kegiatan PkM Dosesn yang diunggah ke aplikasi SIMPEN UT dan Artikel yang dimuat pada Koran Lokal. Berikut adalah Luaran kegiatan PkM Dosen yang direncanakan.

Tabel 1. Luaran Kegiatan PkM Dosen

\begin{tabular}{|l|ll|l|}
\hline No & \multicolumn{2}{|c|}{$\begin{array}{l}\text { Jenis dan Spesifikasi Luaran } \\
\text { Kegiatan }\end{array}$} & \multicolumn{1}{c|}{ Bukti } \\
\hline 1. & $\begin{array}{l}\text { Pelatihan Penulisan } \\
\text { Karya } \\
\text { Penelitian Tindakan } \\
\text { Kelas Pada Guru TK } \\
\text { Di Wilayah Lombok } \\
\text { 1) Laporan PTK tiap } \\
\text { peserta } \\
\text { Artikel Ilmiah dari tiap } \\
\text { peserta }\end{array}$ & $\begin{array}{l}\text { Foto Laporan PTK } \\
\text { yang terkumpul } \\
\text { Sampel 3 laporan } \\
\text { Ilmiah dari peserta }\end{array}$ \\
\hline 2. & $\begin{array}{l}\text { Laporan Pelaksanan PkM } \\
\text { Dosen }\end{array}$ & $\begin{array}{l}\text { Laporan yang } \\
\text { diunggah ke aplikasi } \\
\text { SIMPEN UT }\end{array}$ \\
\hline 3. & Artikel pada koran & $\begin{array}{l}\text { Bukti Kirim Laporan } \\
\text { Kegiatan ke salah } \\
\text { satu Koran Lokal } \\
\text { Misal: Lombok Pos }\end{array}$ \\
\hline
\end{tabular}

\section{METODE PELAKSANAAN}

Pelaksanaan Kegiatan Pengabdian Kepada Masyarakat $(\mathrm{PkM})$ ini akan dilaksanakan melalui metode pelatihan dan pembimbingan intensif kepada peserta. Tahapan kegiatan yang dilakukan adalah sebagai berikut.

Tabel 2. Tahapan Kegiatan PkM

\begin{tabular}{|c|c|c|c|}
\hline No & $\begin{array}{c}\text { Kegiatan yang } \\
\text { dilakukan }\end{array}$ & Pelaksana & Waktu \\
\hline 1. & $\begin{array}{l}\text { Mengidentifikasi } \\
\text { dan menentukan } \\
\text { peserta pelatihan, }\end{array}$ & Mitra & 2 minggu \\
\hline 2. & $\begin{array}{l}\text { Survey dan } \\
\text { Menentukan } \\
\text { tempat kegiatan }\end{array}$ & $\begin{array}{l}\text { Mitra dan } \\
\text { Pelaksana }\end{array}$ & 2 minggu \\
\hline 3. & $\begin{array}{l}\text { Penyiapan materi, } \\
\text { kit dan bahan }\end{array}$ & Pelaksana & 2 minggu \\
\hline 4. & $\begin{array}{l}\text { Penyususnan } \\
\text { instrument } \\
\text { evaluasi program }\end{array}$ & Pelaksana & 2 minggu \\
\hline 5. & $\begin{array}{l}\text { Pelaksanaan } \\
\text { Pelatian dan } \\
\text { Pembimbingan }\end{array}$ & $\begin{array}{l}\text { Pelaksana } \\
\text { UPBJJ UT } \\
\text { Mataram }\end{array}$ & 4 bulan \\
\hline 6. & $\begin{array}{l}\text { Penyusunan } \\
\text { laporan dan Artikel } \\
\text { peserta }\end{array}$ & $\begin{array}{l}\text { Peserta, } \\
\text { Mitra dan } \\
\text { Dosen }\end{array}$ & 1 bulan \\
\hline 7. & Monev Kegiatan & $\begin{array}{l}\text { Mitra dan } \\
\text { Pelaksana }\end{array}$ & 2 minggu \\
\hline 8. & $\begin{array}{l}\text { Penyusunan } \\
\text { laporan Kegiatan } \\
\text { PkM }\end{array}$ & Pelaksana & 1 bulan \\
\hline
\end{tabular}

Tahapan pelaksanaan Pelatihan dan Pembimbingan digambarkan dalam bagan Berikut.

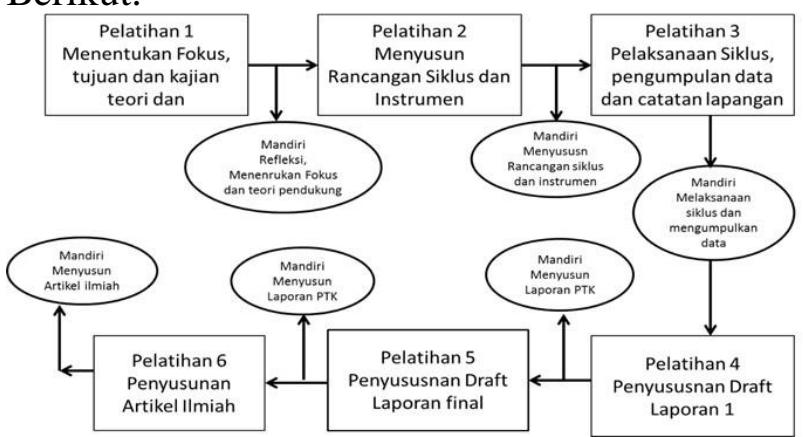

Bagan 1. Tahapan Pelaksanaan PkM

Partisipasi Mitra dalam Pelaksanaan Program. Dalam pelaksanaan kegiatan PkM ini, Mitra, dalam hal ini adalah IGTKI Provinsi NTB, berpartisipasi dalam menyiapkan tempat dan lokasi pelatihan dan pembimbingan, menyiapkan Lembaga TK yang akan digunakan sebagai tempat penelitian dan pengumpulan data (khususnya bagi peserta yang saat ini sedang menjabat di 
Dinas pendidikan sehingga sedang tidak mengajar di TK), dan menyiapkan alat dan bahan praktik dalam penerapan siklus yang dilakukan peserta.

\section{KELAYAKAN PELAKSANA}

\section{a. Pelaksana PkM}

Pelaksana PkM ini adalah Dosendosen di UPBJJ-UT mataram yang memiliki kualifikasi minimal S2 yang sudah berpengalaman dalam melakukan penelitian, termasuk Penelitian Tindakan kelas.Selain itu, para pelaksana juga memiliki pengalaman mengelola kegiatan pembimbingan dan pelatihan khususnya yang dilakukan terhadap guru-guru dari berbagai jenjang pendidikan. Dari Sisi keilmuan, para pelaksana sangat kompeten dalam bidang keilmuannya sehingga akan dapat melatih dan membimbing peserta termasuk dalam menentukan dan menelaah konten penelitian yang akan dilakukan oleh peserta. Hal lain yang mendukung kelayakan pelaksana adalah kesiapan pelaksana dalam program ini karena di UPBJJ Mataram mereka diberi kesempatan seluas-luasnya untuk meengembangkan kemampuan dirinya dan menerapkan keilmuannya sebagai tenaga akademik (Dosen). Berikut adalah Kualifikasi akademik Pelaksana secara Rinci.

Tabel 4. Pelaksana, Keilmuan dan Tugas dalam PkM

\begin{tabular}{|c|c|c|c|}
\hline No & Nama & Keilmuan & $\begin{array}{c}\text { Tugasnya } \\
\text { dalam } \\
\text { Program }\end{array}$ \\
\hline 1. & Drs. Nurdin, M.Pd & $\begin{array}{l}\text { Pendidikan } \\
\text { Bahasa } \\
\text { Indonesia }\end{array}$ & 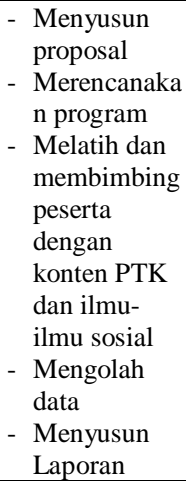 \\
\hline 2. & $\begin{array}{l}\text { Dr. Sri Tatminingsih, } \\
\text { M.Pd }\end{array}$ & PAUD & 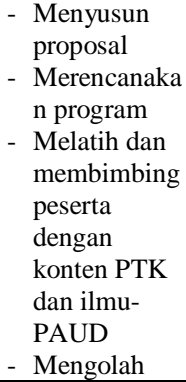 \\
\hline
\end{tabular}

\begin{tabular}{|c|c|c|c|}
\hline No & Nama & Keilmuan & $\begin{array}{c}\begin{array}{c}\text { Tugasnya } \\
\text { dalam } \\
\text { Program }\end{array} \\
\end{array}$ \\
\hline & & & $\begin{array}{l}\text { data } \\
\text { - Menyusun } \\
\text { Laporan }\end{array}$ \\
\hline 3. & Dra. Ramlah, M.Pd & $\begin{array}{l}\text { Pendidikan } \\
\text { Bahasa } \\
\text { Indonesia }\end{array}$ & 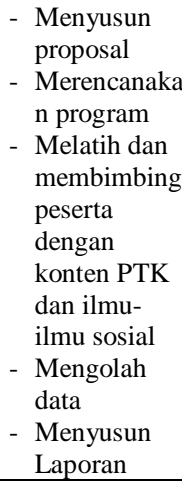 \\
\hline 4. & Hulaifi, S.Pi., M.Agr & $\begin{array}{l}\text { Biologi } \\
\text { MIPA }\end{array}$ & $\begin{array}{l}\text { - Menyusun } \\
\text { proposal } \\
\text { - Merencanaka } \\
\text { n program } \\
\text { - Melatih dan } \\
\text { membimbing } \\
\text { peserta } \\
\text { dengan } \\
\text { konten PTK } \\
\text { dan ilmu } \\
\text { Alam, sains } \\
\text { dan } \\
\text { matematika } \\
\text { - Mengolah } \\
\text { data } \\
\text { - Menyusun } \\
\text { Laporan }\end{array}$ \\
\hline
\end{tabular}

\section{b. Keterlibatan Alumni UT}

Dalam kegiatan PkM Dosen Universitas Terbuka, keterlibatan alumni atau lulusan dari universitas terbuka sangat diperlukan. Hal ini dilakukan untuk memberdayakan para lulusan dalam memajukan kehidupan masyarakat. Berhubung sasaran PkM ini adalah guru-guru Taman Kanak-kanak maka alumni yang dilibatkan adalah alumni UT pada Program Studi Pendidikan Guru Pendidikan Anak Usia Dini (PGPAUD) pada Jurusan Pendidikan Dasar Fakultas Keguruan dan Ilmu Pendidikan (FKIP) yang berada atau berdominisili di Mataram Nusa Tenggara Barat. Keterlibatan alumni dalam kegiatan ini adalah, sebagai penghubung dalam menyampaikan informasi terkait pelaksanaan Pkm dan juga sekaligus sebagai peserta pelatihan yang mempu memotori rekan-rekan guru lainnya. Para alumni ini, juga membantu pelaksanaan dalam hal menginformasikan kepada sesame rekan guru yang terlibat sebagai peserta dalam hal ke UT an. Berikut 
adalah nama-nama alumni UT yang terlibat dalam kegiatan PkM ini.

Tabel 5. Daftar Alumni

\begin{tabular}{|l|l|c|}
\hline No & \multicolumn{1}{|c|}{ Nama } & Keilmuan \\
\hline 1. & Irma Suryani, S.Pd.AUD & PAUD \\
\hline 2. & Nilawati, S.Pd.AUD & PAUD \\
\hline 3. & Hurul Aini, S.Pd.AUD & PAUD \\
\hline 4. & I Gusti Ayu, S.Pd.AUD & PAUD \\
\hline
\end{tabular}

\section{c. Keterlibatan Dosen Luar UT}

Keterlibatan pihak lain, selain mitra dan alumni adalah dosen Luar UT. Keterlibatan dosen luar ini diperlukan agar dalam pelaksanaan PkM bisa lebih menyebar serta untuk dapat terjalinnya kerjasama dengan perguruan tinggi lain di wilayah tempat PkM tersebut dilangsungkan. Dengan adanya kerjasama ini maka diharapkan aakan terjalin kemitraan yang harmonis dan dapat memajukan masyarakat di sekitar Perguruan Tinggi. Dalam Pelaksaan PkM ini, Dosen Luar UT bertugas sebagai Fasilitator bagi para peserta dalam menyusun karya ilmiahnya sekaligus sebagai pengamat dan pelaku proses PkM ini. Dosen Luar UT ini, ikut terlibat mulai dari proses perencanaan, pelaksanaan hingga proses pelaporan. Berikut adalah daftar nama Dosen Luar UT yang terlibat dalam PkM ini.

Tabel 6. Daftar Nama Dosen Luar UT yang Terlibat dalam PkM

\begin{tabular}{|c|c|c|c|}
\hline No & Nama & Keilmuan & Keterangan \\
\hline 1. & Syahrir, M.Pd & $\begin{array}{l}\text { Pendidikan } \\
\text { Matematika }\end{array}$ & $\begin{array}{l}\text { Dosen dan } \\
\text { Editor Jurnal } \\
\text { IKIP Mataram }\end{array}$ \\
\hline 2. & Hafsah, M.Pd & Pendidikan PKn & $\begin{array}{lr}\text { Dosen } & \text { dan } \\
\text { Editor } & \text { Jurnal } \\
\text { FKIP } & \text { UM } \\
\text { Mataram } & \end{array}$ \\
\hline
\end{tabular}

\section{PELAKSANAAN}

\section{KEPADA MASYARAKAT}

\section{PENGABDIAN}

\section{A. Pengembangan Instrumen}

Kegiatan PkM yang dilakukan oleh Dosen-dosen di UT Mataram ini, diawalai dengan penyusunan Proposal dimana di dalamnya termasuk dalam penyusunan kisikisi instrument yang akan digunakan selama dan setelah kegiatan dilakukan. Berdasarkan kisi-kisi tersebut maka disusunlah Instrumen tersebut yang kami masukan dalam proses pelaksanaan. Hal ini karena, penyusunan instrument dilakukan setelah proposal dinyatakan diterima dan bisa dilaksanakan. Instrumen yang kami susun terdiri dari dua instrument, yaitu instrument pelatihan untuk peserta dan instrument asesmen yang akan digunakan oleh pembimbing atau supervisor dalam PkM ini. Berikut adalah dua instrument yang kami kembangkan.

\section{Intrumen Pelatihan Peserta KUESIONER PELATIHAN PENULISAN KARYA ILMIAH}

\section{Identitas}

1. Nama

2. Usia/Tanggal lahir tahun/

3. Status Pegawai

4. Pangkat/Jabatan

5. Alamat email

6. No. Telp/ HP

7. Tempat Mengajar

Jawablah pertanyaan berikut ini dengan jujur dan bertanggungjawab

\begin{tabular}{|c|c|c|c|c|c|c|}
\hline No & Pertanyaan & 1 & 2 & 3 & 4 & 5 \\
\hline A. & \multicolumn{6}{|c|}{ Pengetahuan tentang penelitian } \\
\hline 1. & $\begin{array}{l}\text { Menjelaskan } \\
\text { definisi penelitian }\end{array}$ & & & & & \\
\hline 2. & $\begin{array}{l}\text { Menjelaskan } \\
\text { pengertian } \\
\text { masalah }\end{array}$ & & & & & \\
\hline 3. & $\begin{array}{l}\text { Menjelaskan } \\
\text { tujuan penelitian }\end{array}$ & & & & & \\
\hline 4. & $\begin{array}{l}\text { Menjelaskan } \\
\text { jenis-jenis metode } \\
\text { penelitian }\end{array}$ & & & & & \\
\hline 5. & $\begin{array}{l}\text { Menjelaskan } \\
\text { prinsip-prinsip } \\
\text { ilmiah }\end{array}$ & & & & & \\
\hline 6. & $\begin{array}{l}\text { Menjelaskan } \\
\text { prosedur atau } \\
\text { tahapan penelitian }\end{array}$ & & & & & \\
\hline 7. & $\begin{array}{l}\text { Menjelaskan } \\
\text { definisi Penelitian } \\
\text { Tindakan Kelas }\end{array}$ & & & & & \\
\hline 8. & $\begin{array}{l}\text { Menjelaskan cara } \\
\text { menganalisis data } \\
\text { PTK }\end{array}$ & & & & & \\
\hline 9. & $\begin{array}{l}\text { Menjelaskan cara } \\
\text { membuat } \\
\text { kesimpulan } \\
\text { penelitian }\end{array}$ & & & & & \\
\hline 10. & $\begin{array}{l}\text { Menjelaskan } \\
\text { pengertian abstrak }\end{array}$ & & & & & \\
\hline B. & Pengalaman penel & & & & & \\
\hline 11. & Pernah melakukan & & & & & \\
\hline
\end{tabular}




\begin{tabular}{|c|c|c|c|c|c|c|}
\hline No & Pertanyaan & 1 & 2 & 3 & 4 & 5 \\
\hline & penelitian & & & & & \\
\hline 12. & $\begin{array}{l}\text { Pernah melakukan } \\
\text { Penelitian } \\
\text { Tindakan Kelas }\end{array}$ & & & & & \\
\hline 13. & $\begin{array}{l}\text { Dapat } \\
\text { merumuskan } \\
\text { masalah penelitian }\end{array}$ & & & & & \\
\hline 14. & $\begin{array}{l}\text { Dapat } \\
\text { merumuskan } \\
\text { tujuan penelitian }\end{array}$ & & & & & \\
\hline 15. & $\begin{array}{l}\text { Dapat menentukan } \\
\text { metode penelitian }\end{array}$ & & & & & \\
\hline 16. & $\begin{array}{l}\text { Dapat menyusun } \\
\text { siklus dalam PTK }\end{array}$ & & & & & \\
\hline 17. & $\begin{array}{l}\text { Dapat menuliskan } \\
\text { catatan lapangan }\end{array}$ & & & & & \\
\hline 18. & $\begin{array}{l}\text { Dapat menuliskan } \\
\text { sumber kutipan } \\
\text { (catatan kaki) }\end{array}$ & & & & & \\
\hline 19. & $\begin{array}{l}\text { Dapat membuat } \\
\text { kesimpulan hasil } \\
\text { penelitian }\end{array}$ & & & & & \\
\hline 20. & $\begin{array}{l}\text { Dapat menuliskan } \\
\text { daftar pustaka }\end{array}$ & & & & & \\
\hline 21. & $\begin{array}{l}\text { Pernah membuat } \\
\text { artikel ilmiah } \\
\text { untuk publikasi }\end{array}$ & & & & & \\
\hline 22. & $\begin{array}{l}\text { Artikel yang } \\
\text { ditulis pernah } \\
\text { dimuat dalam } \\
\text { jurnal/ publikasi }\end{array}$ & & & & & \\
\hline 23. & $\begin{array}{l}\text { Mendapat } \\
\text { penghargaan } \\
\text { dalam menulis } \\
\text { artikel ilmiah }\end{array}$ & & & & & \\
\hline C. & Harapan terhadap & atih & nuli & $\operatorname{lmi}$ & & \\
\hline 24. & $\begin{array}{l}\text { Mampu menulis } \\
\text { artikel ilmiah } \\
\text { dengan baik }\end{array}$ & & & & & \\
\hline 25. & $\begin{array}{l}\text { Mampu } \\
\text { melakukan } \\
\text { penelitian PTK } \\
\text { dengan benar } \\
\end{array}$ & & & & & \\
\hline 26. & $\begin{array}{l}\text { Memiliki } \\
\text { pengetahuan } \\
\text { tentang penelitian }\end{array}$ & & & & & \\
\hline 27. & $\begin{array}{l}\text { Memiliki } \\
\text { pengetahuan } \\
\text { tentang karya } \\
\text { ilmiah yang baik }\end{array}$ & & & & & \\
\hline 28. & $\begin{array}{l}\text { Memiliki } \\
\text { kemampuan } \\
\text { dalam menyusun } \\
\text { laporan penelitian }\end{array}$ & & & & & \\
\hline 29. & $\begin{array}{l}\text { Memiliki artikel } \\
\text { yang siap } \\
\text { dipublikasikan }\end{array}$ & & & & & \\
\hline
\end{tabular}

\section{Instrumen Asesmen Peserta} Lembar Asesmen Penulisan Karya Ilmiah

NamaPeserta

Nama Supervisor

\begin{tabular}{|c|c|c|c|c|c|c|c|}
\hline \multirow[t]{2}{*}{ No } & \multirow[t]{2}{*}{ Aspek yang diases } & \multicolumn{5}{|c|}{ Penilaian } & \multirow[t]{2}{*}{ Keterangan } \\
\hline & & 1 & 2 & 3 & 4 & 5 & \\
\hline A. & PERSIAPAN & & & & & & \\
\hline 1. & $\begin{array}{l}\text { Membawa bahan } \\
\text { yang diperlukan } \\
\text { (ATK) }\end{array}$ & & & & & & \\
\hline 2. & $\begin{array}{l}\text { Membawa bahan } \\
\text { untuk didiskusikan } \\
\text { (berupa pertanyaan } \\
\text { atau tanggapan) }\end{array}$ & & & & & & \\
\hline 3. & $\begin{array}{l}\text { Memiliki judul atau } \\
\text { topik karil yang akan } \\
\text { ditulisnya }\end{array}$ & & & & & & \\
\hline 4. & $\begin{array}{l}\text { Membawa sumber } \\
\text { belajar (Buku atau } \\
\text { materi lain) }\end{array}$ & & & & & & \\
\hline 5. & Datang tepat waktu & & & & & & \\
\hline
\end{tabular}

\begin{tabular}{|c|c|c|c|c|c|c|c|}
\hline \multirow[t]{2}{*}{ No } & \multirow[t]{2}{*}{ Aspek yang diases } & \multicolumn{5}{|c|}{ Penilaian } & \multirow[t]{2}{*}{ Keterangan } \\
\hline & & 1 & 2 & 3 & 4 & 5 & \\
\hline B. & $\begin{array}{l}\text { PELAKSANAAN } \\
\text { PELATIHAN }\end{array}$ & & & & & & \\
\hline 1. & $\begin{array}{l}\text { Keaktifan dalam } \\
\text { menggali, } \\
\text { menemukan dan } \\
\text { mengolah informasi }\end{array}$ & & & & & & \\
\hline 2. & $\begin{array}{l}\text { Keseriusan dalam } \\
\text { mengikuti pelatihan }\end{array}$ & & & & & & \\
\hline 3. & $\begin{array}{l}\text { Ketertiban dalam } \\
\text { mengikuti kegiatan } \\
\text { pelatihan }\end{array}$ & & & & & & \\
\hline 4. & $\begin{array}{l}\text { Keaktifan bertanya } \\
\text { selama pelatihan }\end{array}$ & & & & & & \\
\hline 5. & $\begin{array}{l}\text { Keaktifan } \\
\text { memberikan } \\
\text { tanggapan atau } \\
\text { mengungkapkan } \\
\text { pendapatnya selama } \\
\text { pelatihan }\end{array}$ & & & & & & \\
\hline 6. & $\begin{array}{l}\text { Kemampuan } \\
\text { bekerjasama dengan } \\
\text { teman dalam } \\
\text { kelompoknya }\end{array}$ & & & & & & \\
\hline 7. & $\begin{array}{l}\text { Keaktifan dan } \\
\text { ketertiban dalam } \\
\text { diskusi }\end{array}$ & & & & & & \\
\hline 8. & $\begin{array}{l}\text { Kemampuan } \\
\text { merekam hasil } \\
\text { pelatihan }\end{array}$ & & & & & & \\
\hline C. & $\begin{array}{l}\text { HASIL } \\
\text { PELATIHAN }\end{array}$ & & & & & & \\
\hline 1. & $\begin{array}{l}\text { Sistematika } \\
\text { Penulisan }\end{array}$ & & & & & & \\
\hline 2. & $\begin{array}{l}\text { Kekritisan } \\
\text { menganalisis masalah }\end{array}$ & & & & & & \\
\hline 3. & Kelayakan isi & & & & & & \\
\hline 4. & $\begin{array}{l}\text { Kemampuan } \\
\text { menggunakan ejaan }\end{array}$ & & & & & & \\
\hline 5. & $\begin{array}{l}\text { Kemampuan } \\
\text { menggunakan bahasa }\end{array}$ & & & & & & \\
\hline 6. & $\begin{array}{l}\text { Kemampuan } \\
\text { menuliskan sumber } \\
\text { kutipan }\end{array}$ & & & & & & \\
\hline 7. & $\begin{array}{l}\text { Kemampuan } \\
\text { menuliskan daftar } \\
\text { pustaka }\end{array}$ & & & & & & \\
\hline 8. & Kerapihan & & & & & & \\
\hline
\end{tabular}

\section{Rubrik Penilaian Asesmen Peserta Rubrik Asesmen Keterampilan Menulis Karya Ilmiah}

\begin{tabular}{|c|c|c|c|}
\hline NO & ASPEK & DESKRIPTOR & SKOR \\
\hline A. & \multicolumn{3}{|l|}{ PERSIAPAN } \\
\hline 1. & $\begin{array}{l}\text { Membawa } \\
\text { bahan yang } \\
\text { diperlukan } \\
\text { (ATK) }\end{array}$ & 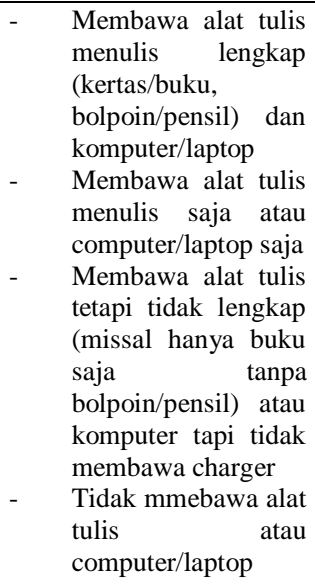 & 4 \\
\hline 2. & $\begin{array}{l}\text { Menyiapkan } \\
\text { bahan untuk } \\
\text { didiskusikan } \\
\text { (berupa }\end{array}$ & $\begin{array}{ll}\text { - } & \text { Membawa } \\
\text { catatan/pertanyaan } \\
\text { dan sudah tertulis } \\
\text { - } \quad \text { Membawa }\end{array}$ & 5 \\
\hline
\end{tabular}




\begin{tabular}{|c|c|c|c|}
\hline NO & ASPEK & DESKRIPTOR & SKOR \\
\hline & $\begin{array}{l}\text { pertanyaan atau } \\
\text { tanggapan) }\end{array}$ & $\begin{array}{l}\text { catatan/pertanyaan } \\
\text { masih dalam pikiran } \\
\text { Memiliki pertanyaan } \\
\text { tetapi tidak tahu } \\
\text { rumusannya } \\
\text { Tidak memiliki } \\
\text { catatan/pertanyaan }\end{array}$ & $\begin{array}{l}4 \\
3 \\
2\end{array}$ \\
\hline 3. & $\begin{array}{l}\text { Memiliki judul } \\
\text { atau topik karil } \\
\text { yang akan } \\
\text { ditulisnya }\end{array}$ & $\begin{array}{ll}- & \text { Memiliki judul } \\
\text { lengkap } \\
\text { - } & \text { Memiliki topik dan } \\
\text { belum berupa judul } \\
\text { - } & \text { Memiliki topik } \\
\text { masih abstrak } \\
\text { - } \\
\text { Tidak memiliki } \\
\text { topik atau judul karil }\end{array}$ & $\begin{array}{l}5 \\
4 \\
3 \\
3 \\
2\end{array}$ \\
\hline 4. & $\begin{array}{l}\text { Membawa } \\
\text { sumber belajar } \\
\text { (buku atau } \\
\text { materi lain) }\end{array}$ & $\begin{array}{ll}\text { - } & \begin{array}{l}\text { Membawa buku dan } \\
\text { sumber belajar }\end{array} \\
\text { sesuai judul karilnya } \\
\text { - } \\
\text { Membawa buku dan } \\
\text { sumber belajar tidak } \\
\text { sesuai judul karil } \\
\text { - Membawa buku atau } \\
\text { sumber belajar saja } \\
\text { tidak sesuai judul } \\
\text { karilnya } \\
\text { Tidak membawa } \\
\text { buku atau sumber } \\
\text { belajar }\end{array}$ & $\begin{array}{l}5 \\
4\end{array}$ \\
\hline 5. & $\begin{array}{l}\text { Datang tepat } \\
\text { waktu }\end{array}$ & $\begin{array}{ll}\text { - } & \begin{array}{l}\text { Datang } 15 \quad \begin{array}{l}\text { menit } \\
\text { sebelum } \\
\text { dimulai }\end{array} \\
\text { - }\end{array} \\
\text { Datang ketika acara } \\
\text { baru dimulai } \\
\text { - } \\
\text { Datang 15 menit } \\
\text { setelah acara dimulai } \\
\text { - } \begin{array}{l}\text { Datang 1 jam setelah } \\
\text { acara dimulai }\end{array} \\
\end{array}$ & $\begin{array}{l}4 \\
3 \\
2\end{array}$ \\
\hline B. & \multicolumn{3}{|c|}{ PELAKSANAAN PELATIHAN } \\
\hline 1. & $\begin{array}{l}\text { Keaktifan } \\
\text { dalam } \\
\text { menggali, } \\
\text { menemukan } \\
\text { dan mengolah } \\
\text { informasi }\end{array}$ & 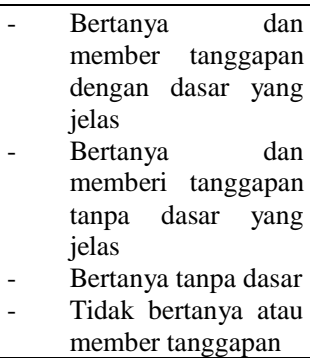 & $\begin{array}{l}3 \\
2\end{array}$ \\
\hline 2. & $\begin{array}{l}\text { Keseriusan } \\
\text { dalam } \\
\text { mengikuti } \\
\text { pelatihan }\end{array}$ & 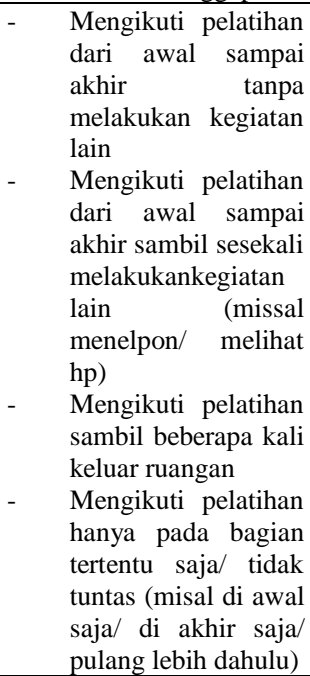 & 4 \\
\hline 3. & $\begin{array}{l}\text { Ketertiban } \\
\text { dalam } \\
\text { mengikuti } \\
\text { kegiatan } \\
\text { pelatihan }\end{array}$ & $\begin{array}{llr}\text { - } & \begin{array}{l}\text { Mengikuti } \\
\text { pelatihan }\end{array} & \text { aturan } \\
\text { dertib } & \text { sengan } \\
\text { kesepakatan } & \\
\text { - } & \text { Melanggar } & \\
\end{array}$ & 5 \\
\hline
\end{tabular}

\begin{tabular}{|c|c|c|c|}
\hline NO & ASPEK & DESKRIPTOR & SKOR \\
\hline & & $\begin{array}{ll} & \text { kesepakatan 1-2 kali } \\
\text { - } & \text { Melanggar } \\
\text { kesepakatan 3-4 kali } \\
\text { Melanggar } \\
\text { kesepakatan 5 kali } \\
\text { atau lebih }\end{array}$ & $\begin{array}{l}4 \\
3 \\
2\end{array}$ \\
\hline 4. & $\begin{array}{l}\text { Keaktifan } \\
\text { bertanya } \\
\text { selama } \\
\text { pelatihan }\end{array}$ & $\begin{array}{ll}\text { - } & \text { Bertanya 5-6 kali } \\
& \text { selama pelatihan } \\
\text { - } & \text { Bertanya 3-4 kali } \\
& \text { selama pelatihan } \\
\text { - } & \text { Bertanya 1-2 kali } \\
\text { selama pelatihan } \\
\text { Tidak pernah } \\
\text { bertanya selama } \\
\text { pelatihan }\end{array}$ & $\begin{array}{l}5 \\
4 \\
3 \\
2\end{array}$ \\
\hline 5. & $\begin{array}{l}\text { Keaktifan } \\
\text { memberikan } \\
\text { tanggapan atau } \\
\text { mengungkapka } \\
\text { n pendapatnya } \\
\text { selama } \\
\text { pelatihan }\end{array}$ & 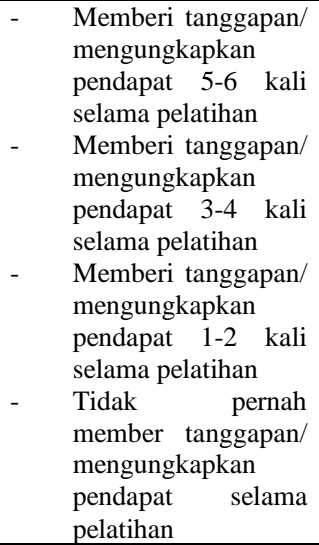 & 3 \\
\hline 6. & $\begin{array}{l}\text { Kemampuan } \\
\text { bekerja sama } \\
\text { dengan teman } \\
\text { dalam } \\
\text { kelompoknya }\end{array}$ & 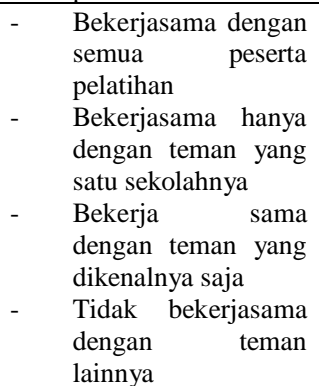 & $\begin{array}{l}3 \\
2\end{array}$ \\
\hline 7. & $\begin{array}{l}\text { Keaktifan dan } \\
\text { ketertiban } \\
\text { dalam diskusi }\end{array}$ & 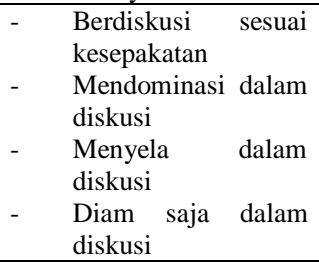 & $\begin{array}{l}5 \\
4 \\
4 \\
3 \\
2\end{array}$ \\
\hline 8. & $\begin{array}{l}\text { Kemampuan } \\
\text { merekam hasil } \\
\text { pelatihan }\end{array}$ & 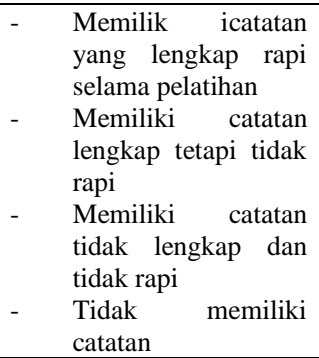 & $\begin{array}{l}4 \\
3\end{array}$ \\
\hline C. & \multicolumn{3}{|c|}{ HASIL PELATIHAN } \\
\hline 1. & $\begin{array}{l}\text { Sistematika } \\
\text { Penulisan }\end{array}$ & $\begin{array}{l}\text { Jika sistematika } \\
\text { karya tulis ilmiah } \\
\text { lengkap dan urut } \\
\text { (halaman judul, } \\
\text { prakata, daftar isi, } \\
\text { pendahuluan [latar } \\
\text { belakang, rumusan } \\
\text { masalah, tujuan, } \\
\text { manfaat], landasan } \\
\text { teoretis, metode }\end{array}$ & 5 \\
\hline
\end{tabular}




\begin{tabular}{|c|c|c|c|}
\hline NO & ASPEK & DESKRIPTOR & SKOR \\
\hline & & $\begin{array}{l}\text { penelitian, } \\
\text { pembahasan, dan } \\
\text { penutup [simpulan } \\
\text { dan saran], dan } \\
\text { daftar pustaka) } \\
\text { Jika sistematika } \\
\text { karya tulis ilmiah } \\
\text { tidak lengkap tetapi } \\
\text { urut. } \\
\text { Jika sistematika } \\
\text { karya tulis ilmiah } \\
\text { lengkap tetapi tidak } \\
\text { urut sistematika } \\
\text { Jika ilmiah } \\
\text { karya tulis ilm } \\
\text { tidak lengkap dan } \\
\text { tidak urut }\end{array}$ & 2 \\
\hline 2. & $\begin{array}{l}\text { Kekritisan } \\
\text { menganalisis } \\
\text { masalah }\end{array}$ & 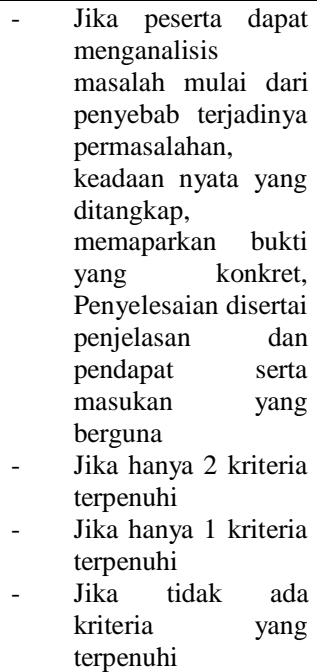 & $\begin{array}{l}4 \\
3 \\
2\end{array}$ \\
\hline 3. & Kelayakan isi & $\begin{array}{lr}\text { gagasan } & \text { yang } \\
\text { dituliskan sesuai } & \text { topic } \\
\text { dengan } & \\
\text { permasalahan, } \\
\text { didukung dengan } \\
\text { teori, alasan, bukti } \\
\text { yang jelas, solusi } \\
\text { yang diberikan } \\
\text { sesuai dengan topic } \\
\text { permasalahan. } \\
\text { Informasi yang } \\
\text { dituliskan sesuai } \\
\text { dengan topic } \\
\text { permasalahan, teori, } \\
\text { alasan dan bukti } \\
\text { sudah ada namun } \\
\text { kurang mendukung } \\
\text { permasalahan, solusi } \\
\text { yang diberikan } \\
\text { cukup sesuai dengan } \\
\text { topik permasalahan } \\
\text { Gagasan yang } \\
\text { disampaikan sesuai } \\
\text { dengan topic } \\
\text { permasalahan, } \\
\text { didukung dengan } \\
\text { teori dan argumen } \\
\text { yang jelas, namun } \\
\text { solusi yang } \\
\text { disampaikan tidak } \\
\text { sesuai dengan topik } \\
\text { permasalahn } \\
\text { Gagasan } \\
\text { disampaikan tidak } \\
\text { sesuai dengan topik } \\
\text { permasalahan, teori, } \\
\text { alasan dan bukti }\end{array}$ & 3 \\
\hline
\end{tabular}

\begin{tabular}{|c|c|c|c|}
\hline NO & ASPEK & DESKRIPTOR & SKOR \\
\hline & & \begin{tabular}{lr} 
kurang & \multicolumn{2}{r}{ mendukung } \\
dan solusi yang & tidak \\
diberikan & tik \\
sesuai dengan & topik \\
permasalahan. &
\end{tabular} & \\
\hline 4. & $\begin{array}{l}\text { Kemampuan } \\
\text { menggunakan } \\
\text { ejaan }\end{array}$ & $\begin{array}{ll}\text { - } & \text { Kesalahan } \\
\text { penggunaan ejaan } \\
\text { kurang dari } 5 \text { kata } \\
\text { Kesalahan } \\
\text { penggunaan ejaan } \\
\text { antara 5-10 kata } \\
\text { Kesalahan ejaan } \\
\text { antara 10-15 kata } \\
\text { Kesalahan lebih dari } \\
15 \text { kata }\end{array}$ & $\begin{array}{l}4 \\
3 \\
2\end{array}$ \\
\hline 5. & $\begin{array}{l}\text { Kemampuan } \\
\text { menggunakan } \\
\text { bahasa }\end{array}$ & $\begin{array}{l}\text { Menggunakan diksi } \\
\text { yang tepat, } \\
\text { menggunakan } \\
\text { kalimat efektif, } \\
\text { mudah dipahami } \\
\text { Menggunakan diksi } \\
\text { yang tepat, ada } \\
\text { beberapa kalimat } \\
\text { yang tidak efektif } \\
\text { namun tetap mudah } \\
\text { dipahami } \\
\text { Menggunakan diksi } \\
\text { yang tidak tepat, } \\
\text { menggunakan } \\
\text { kalimat efektif, dan } \\
\text { cukup mudah } \\
\text { dipahami tidak } \\
\text { menggunakan diksi } \\
\text { yang tepat, } \\
\text { Tidak menggunakan } \\
\text { kalimat efektif dan } \\
\text { sulit dipahami. }\end{array}$ & 5 \\
\hline 6. & $\begin{array}{l}\text { Kemampuan } \\
\text { menuliskan } \\
\text { sumber kutipan }\end{array}$ & $\begin{array}{ll}\text { - } & \text { Jika semua sumber } \\
\text { kutipan ditulis sesuai } \\
\text { dengan kaidah } \\
\text { Bahasa Indonesia } \\
\text { - } \\
\text { Jika sumber kutipan } \\
\text { salah 1-2 } \\
\text { Jika sumber kutipan } \\
\text { salah 3-4 } \\
\text { Jika sumber kutipan } \\
\text { salah lebih dari 5-6 }\end{array}$ & $\begin{array}{l}4 \\
3 \\
2\end{array}$ \\
\hline 7. & $\begin{array}{l}\text { Kemampuan } \\
\text { menuliskan } \\
\text { daftar pustaka }\end{array}$ & 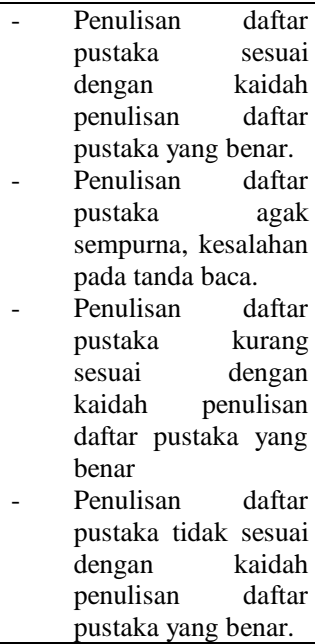 & 5 \\
\hline 8. & Kerapihan & $\begin{array}{l}\text { Tulisan terbaca, } \\
\text { tidak ada coretan } \\
\text { dan disusun secara } \\
\text { rapi/diketik } \\
\text { Tulisan terbaca dan } \\
\text { diketik } \\
\text { Tulisan terbaca tapi } \\
\text { tidak rapi }\end{array}$ & $\begin{array}{l}4 \\
3\end{array}$ \\
\hline
\end{tabular}




\begin{tabular}{|l|l|l|l|}
\hline NO & ASPEK & DESKRIPTOR & SKOR \\
\hline & & $-\begin{array}{l}\text { Tulisan tidak terbaca } \\
\text { dan tidak rapi. }\end{array}$ & 2 \\
\hline
\end{tabular}

Kedua instrumen tersebut beserta rubriknya digunakan setelah divalidasi oleh dua orang pakar yang ditunjuk oleh Pelaksana PkM, yaitu Ibu Dr. Dwi Istati Rahayu, M.Si dari PGPAUD Universitas Mataram sebagai ahli PAUD dan Sosiometri yang cukup lama berkecimpung dalam Lembaga Pengembangan Instrumendan Dosen PAUD dan Bapak Ikslash, M.Pd. sebagai Praktisi PAUD. Berdasarkan hasil validasi keduanya, Kedua instrument tersebut valid untuk digunakan sebagai alat pengukur dalam PkM ini. Instrumen 1, pada awalnya berjumlah 32 Butir Indikator, dinyatakan gugur 3 item, yaitu pada indicator dapat melaksanakan PTK, Dapat menggunakan statistic atau perhitungan oleh data dan dapat mepublikasikan karya ilmiah. Ketiga indicator tersebut dianggap akan sulit icapai melalui PkM ini. Sedangkan pada Instrumen 2, semua item indicator dinyatakan layak dan valid digunakan dalam pengukuran PkM ini.

\section{PELAKSANAAN PKM}

Kegiatan Pkm ini dilaksakan dalam 5 tahap, yang dijabarkan sebagai berikut.

\section{Tahap Persiapan}

Tim pelaksana melakukan beberapa kegiatan, yaitu:

a. Mengidentifikasi nama-nama guru yang dapat dilibatkan dalam pelatihan.

Tim berhubungan dengan ketua IGTKI Provinsi NTB, yaitu Ibu Hamayu, S,Pd. Beliau adalah Kepala TK Pembina Cakranegara yang menjabat sebagai ketua IGTKI NTB. Melalui ketua IGTKI ini, Tim memperoleh nama-nama calon peserta yang akan dilibatkan dalam pelatihan sesuai dengan kebutuhan dan kepentingan serta permasalahan yang dihadapi. Nama-nama tersebut adalah sebagai berikut.

Tabel 6. Daftar Nama Calon Peserta Pelatihan

\begin{tabular}{|r|l|l|l|}
\hline No & \multicolumn{1}{|c|}{ Nama } & Pangkat/Golongan & \multicolumn{1}{|c|}{$\begin{array}{c}\text { Tempat } \\
\text { Bekerja }\end{array}$} \\
\hline 1. & $\begin{array}{l}\text { Hj. Fikriah, } \\
\text { S.Pd }\end{array}$ & Pembina IV/a & $\begin{array}{l}\text { TK PGRI } \\
\text { Mataram }\end{array}$ \\
\hline 2. & $\begin{array}{l}\text { Siti Sarah, } \\
\text { S.Pd }\end{array}$ & Pembina IV/a & $\begin{array}{l}\text { TK NU } \\
\text { Dasan Agung }\end{array}$ \\
\hline
\end{tabular}

\begin{tabular}{|c|c|c|c|}
\hline No & Nama & Pangkat/Golongan & $\begin{array}{l}\text { Tempat } \\
\text { Bekerja }\end{array}$ \\
\hline 3. & $\begin{array}{l}\text { Baiq Mardiani, } \\
\text { S.Pd }\end{array}$ & Pembina IV/a & $\begin{array}{l}\text { TK Fathul } \\
\text { Mubin Cakra }\end{array}$ \\
\hline 4. & $\begin{array}{l}\text { Rosalia Sri } \\
\text { Kadarini, S.Pd }\end{array}$ & Pembina IV/a & $\begin{array}{l}\text { TK ST Don } \\
\text { Bosko }\end{array}$ \\
\hline 5. & $\begin{array}{l}\text { Irma Suryani, } \\
\text { S.Pd }\end{array}$ & ALUMNI UT & $\begin{array}{l}\text { RA NW } \\
\text { Narmada }\end{array}$ \\
\hline 6. & $\begin{array}{l}\text { Hj. Heni } \\
\text { Herawati, } \\
\text { S.Pd., MM }\end{array}$ & Pembina IV/a & $\begin{array}{l}\text { TK N } \\
\text { Pembina } \\
\text { Mataram }\end{array}$ \\
\hline 7. & $\begin{array}{l}\text { Sri } \\
\text { Hartiningsih, } \\
\text { S.Pd }\end{array}$ & Penata Tk. I III/d & $\begin{array}{l}\text { TK } \\
\text { Darmawanita } \\
\text { I Mtr }\end{array}$ \\
\hline 8. & $\begin{array}{l}\text { Baiq Ramiah, } \\
\text { S.Pd }\end{array}$ & Pembina IV/a & $\begin{array}{l}\text { TK N } \\
\text { Pembina } \\
\text { Ampenan }\end{array}$ \\
\hline 9. & Rohayati, S.Pd & Pen. Md. Tk I III/b & $\begin{array}{l}\text { TK PGRI } \\
\text { Cakranegara }\end{array}$ \\
\hline 10. & $\begin{array}{l}\text { Hj. Gustiati, } \\
\text { S.Pd }\end{array}$ & Pembina IV/a & $\begin{array}{l}\text { TK AL Hilal } \\
\text { Ampenan }\end{array}$ \\
\hline 11. & $\begin{array}{l}\text { Nurhikmah, } \\
\text { S.Pd. }\end{array}$ & Pembina IV/a & $\begin{array}{l}\text { TK Tunjung } \\
\text { Sari Ampn }\end{array}$ \\
\hline 12. & $\begin{array}{l}\text { Hj. Fariati, } \\
\text { S.Pd., M.Pd }\end{array}$ & Penata Tk. I III/d & $\begin{array}{l}\text { TK Aisiyah } 3 \\
\text { Mataram }\end{array}$ \\
\hline 13. & $\begin{array}{l}\text { Suryaningsih, } \\
\text { S.Pd }\end{array}$ & Penata III/c & $\begin{array}{l}\text { TK Kemala } \\
\text { Bayangkari }\end{array}$ \\
\hline 14. & Iswati, S.Pd & Penata Tk. I III/d & $\begin{array}{l}\text { TK N Pemb. } \\
\text { Cakranegara }\end{array}$ \\
\hline 15. & $\begin{array}{l}\text { Hamayu } \\
\text { Rohani, S.Pd. }\end{array}$ & Pembina IV/a & $\begin{array}{l}\text { TK N Pemb. } \\
\text { Cakranegara }\end{array}$ \\
\hline 16. & $\begin{array}{l}\text { Nunung } \\
\text { Faukanur, } \\
\text { S.Pd. }\end{array}$ & Pembina IV/a & $\begin{array}{l}\text { TK Alang- } \\
\text { alang }\end{array}$ \\
\hline 17. & $\begin{array}{l}\text { Muji Rahayu, } \\
\text { S.Pd. }\end{array}$ & Pembina IV/a & $\begin{array}{l}\text { TK N Pemb. } \\
\text { Cakranegara }\end{array}$ \\
\hline 18. & $\begin{array}{l}\text { Hj. Ropa'ah, } \\
\text { S.Pd }\end{array}$ & Penata Tk. I III/d & $\begin{array}{l}\text { TK PGRI } \\
\text { Mataram }\end{array}$ \\
\hline 19. & Hadfijah, S.Pd & ALUMNI UT & $\begin{array}{l}\text { RA Qaruniah } \\
\text { Batu Kuta }\end{array}$ \\
\hline 20. & $\begin{array}{l}\text { I Gusti Ayu } \\
\text { Sri } \\
\text { Adnyaswari }\end{array}$ & ALUMNI UT & $\begin{array}{l}\text { TK Tunjung } \\
\text { Sari Ampn }\end{array}$ \\
\hline
\end{tabular}

Setelah data calon peserta diperoleh, kegiatan selanjutnya adalah menghubungi masing-masing peserta untuk meminta kesediaannya mengikuti pelatihan ini. Setelah dihubungi, semua calon peserta menyatakan siap mengikuti kegiatan $\mathrm{PkM}$ ini dengan senang hati dan siap menyisihkan waktunya untuk kegiatan pelatihan

Penulisan karya ilmiah ini dan mereka juga menyatakan komitmen nya untuk menyelesaikan tugas-tugasnya hingga akhir (sampai menghasilkan Karya Ilmiah atau Laporan Penelitian). Setelah Peserta menyatakan kesediaannya, kemudian Tim menyusun jadwal pelaksanaan kegiatan beserta penentuan tempat pelaksanaan 
kegiatan. Berikut adalah Jadwal pelaksanaan kegiatan yang direncanakan tersebut.

Tabel 7. Jadwal Pelaksanaan Kegiatan Pelatihan Penulisan Karya Ilmiah

Guru TK se Wilayah Pulau Lombok

\begin{tabular}{|c|c|c|c|c|}
\hline No & Kegiatan & Sub Kegiatan & Tempat & Tanggal \\
\hline 1. & $\begin{array}{l}\text { Pelatihan } \\
\text { Penulisan } \\
\text { Karya } \\
\text { Ilmiah } \\
\text { Pertemuan } \\
1\end{array}$ & $\begin{array}{ll}\text { 1. } & \text { Menentukan } \\
& \text { Fokus dan } \\
\text { Judul Artikel } \\
\text { 2. } & \begin{array}{l}\text { Pembagian } \\
\text { 3. }\end{array} \\
\text { 3. } & \text { Pembervisor } \\
& \text { Penulisan Latar } \\
& \text { Belakang, } \\
& \text { Kajian Teori } \\
\text { dan Metode } \\
\text { Penelitian } \\
\text { hingga Laporan }\end{array}$ & $\begin{array}{c}\text { TKN } \\
\text { Pembina } \\
\text { Mataram }\end{array}$ & $11 / 9 / 2018$ \\
\hline 2. & $\begin{array}{l}\text { Kegiatan } \\
\text { Mandiri } 1\end{array}$ & $\begin{array}{ll}\text { 1. } & \text { Menyusun BAB } \\
& 1-3 \text { secara } \\
\text { mandiri } \\
\text { 2. } & \text { Pembimbingan } \\
\text { secara online } \\
\text { antara peserta } \\
\text { dengan } \\
\text { Supervisor }\end{array}$ & $\begin{array}{l}\mathrm{Di} \text { Lokasi } \\
\text { masing- } \\
\text { masing }\end{array}$ & $\begin{array}{c}12- \\
21 / 9 / 2018\end{array}$ \\
\hline 3. & $\begin{array}{l}\text { Pembim } \\
\text { bingan } \\
\text { Individual }\end{array}$ & $\begin{array}{ll}\text { 1. } & \text { Konsultasi } \\
\text { penulisan BAB } \\
1-3 \\
\text { 2. } & \begin{array}{l}\text { Penyampaian } \\
\text { penyusunan }\end{array} \\
\text { BAB 4-5 } \\
\text { 3. } & \begin{array}{l}\text { Penjelasan } \\
\text { tentang Daftar } \\
\text { Pustaka }\end{array}\end{array}$ & $\begin{array}{l}\text { Di lokasi } \\
\text { Masing- } \\
\text { masing } \\
\text { secara } \\
\text { individual }\end{array}$ & $\begin{array}{c}22- \\
29 / 92018\end{array}$ \\
\hline 4. & $\begin{array}{l}\text { Kegiatan } \\
\text { Mandiri } 2\end{array}$ & $\begin{array}{l}\text { Penyusunan BAB 4-5, } \\
\text { abstrak dan Daftar } \\
\text { Pustaka }\end{array}$ & $\begin{array}{l}\text { Di lokasi } \\
\text { masing- } \\
\text { masing } \\
\text { secara } \\
\text { individual }\end{array}$ & $\begin{array}{l}1-17 \\
/ 9 / 2018\end{array}$ \\
\hline 5. & Finalisasi & $\begin{array}{ll}\text { 1. } & \text { Penyerahan } \\
\text { Hasil PkM } \\
\text { 2. } & \begin{array}{l}\text { Penutupan } \\
\text { pelatihan }\end{array}\end{array}$ & $\begin{array}{l}\text { TK } \\
\text { Pembina } \\
\text { Mataram }\end{array}$ & $18 / 11 / 2018$ \\
\hline
\end{tabular}

Kegiatan dalam proses persiapan selanjutnya adalah mempersiapkan bahan presentasi (lampiran 1) dan ATK dan berkas seperti daftar hadir (lampiran 2) dan form biodata peserta (lampiran 3) serta penggandaan instrument dan bahan-bahan pendukung lainnya.

\section{Tahap Pertemuan 1}

Pertemuan satu ini merupakan tahap awal dimana peserta berkumpul untuk pertama kalinya. Pada pertemuan ini kegiatan utama adalah penyampaian konsep dan cara menulis artikel untuk karya ilmiah dan pembagian kelompok Supervosir serta focus bidang pengembangan yang akan diteliti dengan Penelitian Tindakan Kelas. Kegiatan dilaksanakan di TK N Pembina Mataram pada tanggal 11 September 2018. Peserta pelatihan yang hadir sebanyak 20 orang, sedangkan seluruh anggota Tim Pelaksana dan Dosen Luar UT juga hadir semua. Berikut adalah daftar seluruh daftar peserta dan pelaksana yang hadir dalam kegiatan tersebut.

Tabel 8. Nama Peserta Pelatihan

\begin{tabular}{|c|c|c|}
\hline No & Nama & Tempat Bekerja \\
\hline \multicolumn{3}{|l|}{ PESERTA } \\
\hline 1. & Hj. Fikriah, S.Pd & TK PGRI Mataram \\
\hline 2. & SITI SARAH, S.Pd & $\begin{array}{l}\text { TK Masitah NU Dasan } \\
\text { Agung }\end{array}$ \\
\hline 3. & Baiq Mardiani, S.Pd & TK Fathul Mubin Cakra \\
\hline 4. & Rosalia Sri Kadarini, S.Pd & TK ST Don Bosko \\
\hline 5. & Irma Suryani, S.Pd & $\begin{array}{l}\text { RA Nurul Huda NW } \\
\text { Narmada }\end{array}$ \\
\hline 6. & Hj. Heni Herawati, S.Pd., MM & TK N Pembina Mataram \\
\hline 7. & Sri Hartiningsih, S.Pd & $\begin{array}{l}\text { TK Darmawanita I } \\
\text { Mataram }\end{array}$ \\
\hline 8. & Baiq Ramiah, S.Pd & TK N Pembina Ampenan \\
\hline 9. & Rohayati, S.Pd & TK PGRI Cakranegara \\
\hline 10. & Hj. Gustiati, S.Pd & TK AL Hilal Ampenan \\
\hline 11. & Nurhikmah, S.Pd. & $\begin{array}{l}\text { TK Tunjung Sari } \\
\text { Ampenan }\end{array}$ \\
\hline 12. & Hj. Fariati, S.Pd., M.Pd & TK Aisiyah 3 Mataram \\
\hline 13. & Suryaningsih, S.Pd & TK Kemala Bayangkari \\
\hline 14. & Iswati, S.Pd & $\begin{array}{l}\text { TK N Pembina } \\
\text { Cakranegara }\end{array}$ \\
\hline 15. & Hamayu Rohani, S.Pd. & $\begin{array}{l}\text { TK N Pembina } \\
\text { Cakranegara }\end{array}$ \\
\hline 16. & Nunung Faukanur, S.Pd. & TK Alang-alang \\
\hline 17. & Muji Rahayu, S.Pd. & $\begin{array}{l}\text { TK N Pembina } \\
\text { Cakranegara }\end{array}$ \\
\hline 18. & Hj. Ropa'ah, S.Pd & TK PGRI Mataram \\
\hline 19. & Hadfijah, S.Pd & RA Qaruniah Batu Kuta \\
\hline 20. & I Gusti Ayu Sri Adnyaswari & $\begin{array}{l}\text { TK Tunjung Sari } \\
\text { Ampenan }\end{array}$ \\
\hline \multicolumn{3}{|c|}{ TIM PELAKSNAKA } \\
\hline 21. & Drs. Nurdin, M.Pd & Universitas Terbuka \\
\hline 22. & Dra. Ramlah AG, M.PD & Universitas Terbuka \\
\hline 23. & Dr. Sri Tatminingsih, M.Pd & Universitas Terbuka \\
\hline 24. & Hulaifi, S.Agr. M.Agr & Universitas terbuka \\
\hline 25. & Dra. Angkasa, M.Pd & Universitas Terbuka \\
\hline \multicolumn{3}{|c|}{ DOSEN LUAR UT } \\
\hline 26. & Syahrir, M.Pd & IKIP Mataram \\
\hline 27. & Hafsah, M.Pd & FKIP UM Mataram \\
\hline
\end{tabular}

\section{Tahap Kegiatan Mandiri}

Kegiatan mandiri dilakukan secara individual oleh masing-masing pesrta dengan supervisor atau pembimbingnya. Konsultasi dilakukan secara online, baik menggunakan email, aplikasi Whatsapp ataupun Line dan aplikasi lainnya.

\section{Tahap Pertemuan 2}

Tahap pertemuan 2 dilakuakn secara individual, dimana masing-masing pembimbing membantu dan membimbing para peserta sesuai dengan kesepakatan masing-masing. Pada tahap ini, peserta sudah mulai menulis dan berkonsultasi melalui media misalnya melalui WA ataupun email. Berikut adalah daftar nama pembimbing, peserta dan judul karya tulis peserta.

Tabel 9. Daftar Pembimbing, Peserta dan Judul Karya Ilmiah

\begin{tabular}{|c|c|l|l|}
\hline No & Pembimbing & \multicolumn{1}{|c|}{ Peserta } & Judul Karya IL miah \\
\cline { 1 - 1 } A. & & Hj. Fikriah, S.Pd & "Upaya Meningkatkan \\
\cline { 1 - 1 } 1. & Sri & & Kemampuan Motorik \\
& Tatminingsih & & $\begin{array}{l}\text { Halus Anak Melalui } \\
\text { Kegiatan Menjiplak }\end{array}$ \\
\hline
\end{tabular}




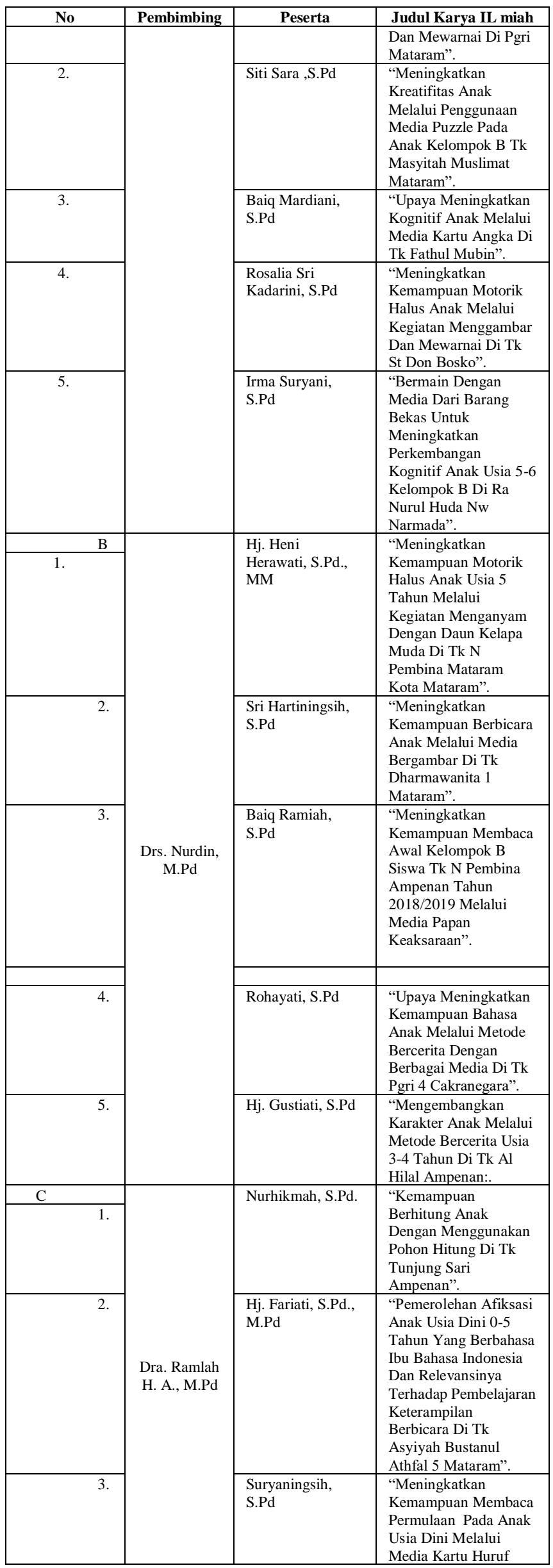

\begin{tabular}{|c|c|c|c|}
\hline No & Pembimbing & Peserta & Judul Karya IL miah \\
\hline & & & $\begin{array}{l}\text { Dalam Pembelajaran } \\
\text { Kemampuan Berbahasa } \\
\text { Pada Kelompok B 1 Tk } \\
\text { Kemala Bhayangkari } \\
\text { 01 Mataram. }\end{array}$ \\
\hline 4. & & Iswati, S.Pd & $\begin{array}{l}\text { "Upaya Meningkatkan } \\
\text { Keterampilan } \\
\text { Berbahasa Anak Usia } \\
\text { Dini Melalui Bermain } \\
\text { Peran Di Tk N } \\
\text { Pembina". }\end{array}$ \\
\hline D. & \multirow{3}{*}{$\begin{array}{l}\text { Hulaifi, } \\
\text { S.Psi., } \\
\text { M.Agr }\end{array}$} & \multirow{2}{*}{$\begin{array}{l}\text { Hamayu Rohani, } \\
\text { S.Pd. }\end{array}$} & \multirow{2}{*}{$\begin{array}{l}\text { "Upaya Meningkatkan } \\
\text { Kemampuan Anak } \\
\text { Tentang Pemahaman } \\
\text { Konsep Bilangan Di Tk } \\
\text { N Pembina". }\end{array}$} \\
\hline 1. & & & \\
\hline 2. & & $\begin{array}{l}\text { Nunung Faukanur } \\
\text {, S.Pd. }\end{array}$ & $\begin{array}{l}\text { "Kemampuan } \\
\text { Meningkatkan } \\
\text { Kemampuan Berbahasa } \\
\text { Anak Dengan Metode } \\
\text { Story Telling Di Paud } \\
\text { Alang-Alang". }\end{array}$ \\
\hline E. & \multirow{3}{*}{$\begin{array}{l}\text { Baiq Sarlita, } \\
\text { M.Pd }\end{array}$} & \multirow{2}{*}{$\begin{array}{l}\text { Muji Rahayu, } \\
\text { S.Pd. }\end{array}$} & \multirow{2}{*}{$\begin{array}{l}\text { "Meningkatkan } \\
\text { Kemampuan Motorik } \\
\text { Halus Anak Melalui } \\
\text { Melipat Di Tk N } \\
\text { Pembina". }\end{array}$} \\
\hline 1. & & & \\
\hline 2. & & Hj. Ropa'ah, S.Pd & $\begin{array}{l}\text { "Upaya Meningkatkan } \\
\text { Kemampuan Menerima } \\
\text { Bahasa Pada Anak } \\
\text { Melalui Metode } \\
\text { Bercerita". }\end{array}$ \\
\hline F. & \multirow{3}{*}{$\begin{array}{l}\text { Muhammad } \\
\text { M. Zainul } \\
\text { Irfan, M.Pd }\end{array}$} & \multirow{2}{*}{$\begin{array}{l}\text { I Gusti Ayu Sri } \\
\text { Adnyaswari, S.Pd. }\end{array}$} & "Penerapan Bermain \\
\hline 1. & & & $\begin{array}{l}\text { Konstruktif Untuk } \\
\text { Meningkatkan } \\
\text { Kreatifitas Anak Pada } \\
\text { Kelompok A Tk } \\
\text { Tunjung Sari Ampenan } \\
\text { Tahun 2018/2019. }\end{array}$ \\
\hline 2. & & Hadijah, S.Pd & $\begin{array}{l}\text { "Meningkatkan } \\
\text { Kemampuan Motorik } \\
\text { Halus Anak Melalui } \\
\text { Kegiatan Mewarnai } \\
\text { Gambar Dengan } \\
\text { Pelepas Pisang Di Ra } \\
\text { Quraniah Batu Kuta". }\end{array}$ \\
\hline
\end{tabular}

\section{Tahap Kegiatan Mandiri}

Tahap Kegiatan Mandiri yang kedua ini dilakukan secara online melalui berbagai media yang memungkinkan, seperti email, WA, telepon ataupun aplikasi komunikasi lainnya. Dalam kegiatan ini peserta berkonsultasi secara intens dengan supervisor atau pembimbingnya terkail kegiatan penelitian dan tugas penulisan karya ilmiahnya baik dari segi konten (keilmuan) maupun dari segi metodologi dan sistematika nya. Hasil proses pembimbingan pada tahap mandiri ini dikumpulkan pada pertemuan ketiga, atau tahap finalisasi yang dilakukan tanggal 18 November 2018. Selama proses pembimbingan ini, supervisor melakukan asesmen terhadap peserta yang menjadi tanggung jawabnya. Asesmen ini dilakukan menggunakan instrument yang telah disusun dan disiapkan sebelumnya 
oleh Tim Pelaksana. Hasil analisis yang dilakukan dengan kuantitatif sederhana dan deskriptif akan disampaikan dalam bentuk deskriptif pada bagian tersendiri.

\section{Tahap Finalisasi (Pertemuan 3)}

Tahap pertemuan 3 dilaksanakan di TK Negeri Pembina Mataram pada tanggal 18 November 2018. Pada pertemuan 3 ini peserta mengkonsultasikan tulisan akhirnya dan memfinalkannya serta menyerahkan karya ilmiah yang sudah final tersebut kepada Tim Pelaksana. Hasil pekerjaan setiap peserta dikumpulkan dalam bentuk soft file. Dalam laporan ini, kamu lampirkan 2 hasil karya peserta.

\section{B. Analsis Hasil PkM}

1. Identitas Peserta

a. Jenis Kelamin, status dan pekerjaan.

Seluruh peserta dalam kegiatan ini berjenis kelamin perempuan dengan status sudah berkeluarga dan bekerja sebagai guru TK. Hal ini menunjukkan bahwa memang sebagian besar guru pada PAUD khususnya TK adalah kaum perempuan. Meskipun kemungkinan ada juga laki-laki namun jumlahnya tidak banyak. Jika kita melihat perbandingan guru perempuan dan laki-laki pada tahun berdasarkan Data Pusat Statistik tahun 2015/2016 dalam (https://www.panduanmengajar.com/2016/10/ guru-perempuan.html) tampak bahwa memang sebagian besar guru (63\%) didominasi oleh perempuan. Khususnya pada jenjang TK, Nampak bahwa 95, 18\% gurunya adalah perempuan.

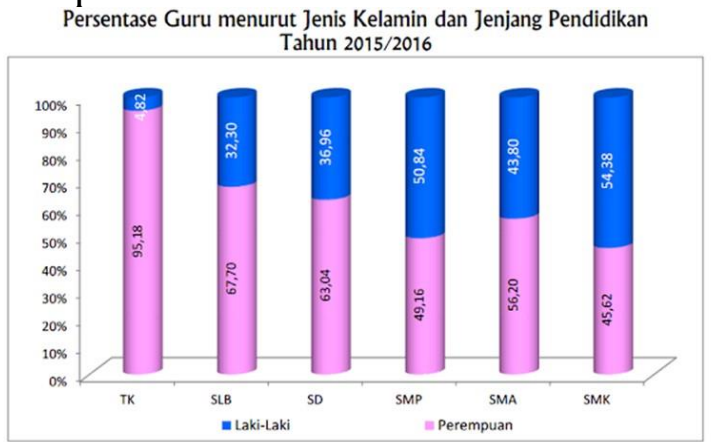

Grafik 1 Perbandingan Guru Perempuan dan

Laki-laki tahun Pelajaran 2015/2016

(https://www.panduanmengajar.com/2016/10/gur u-perempuan.html)

Hasil Penelitian Theresia Alviani Sum dan Adriani Tamo Ina Talu (2018: 137-273) dinyatakan bahwa laki-laki kurang berminat menjadi guru PAUD atau TK karena beberapa alasan yang disampaikan oleh responden lakilaki, yaitu: 1) merasa malu, gengsi karena harus berkutat dengan anak-anak. Selain itu mereka juga kebanyakan laki-laki tidak tahu cara mendidik anak; 2) laki-laki tidak suka anak kecil; 3) merasa gengsi. Mereka merasa menjadi cemen dan banci jika menjadi guru PAUD dan hal itu juga dapat menurunkan martabat laki-laki d. Mereka menganggap bahwa hanya perempuan yang bisa dan sanggup menjadi pendidik PAUD atau mengurusi anak-anak kecil; 5) Laki-laki di wilayah Manggarai itu kuat dan tangguh sehingga mereka merasa tidak cocok untuk menjadi guru PAUD; 6) dan yang terakhir, mereka merasa bahwa kaum laki-laki keras adalah orang-orang yang keras dan tidak sabar sehingga tidak mungkin menjadi guru PAUD yang membutuhkan kelembutan dan kesabaran saat menghadapi anak-anak didiknya.

Pendapat Theresia sesungguhnya tidak sejalan dengan pendapat Meni Tsigra (2014) yang mengutip (http://peranguru-laki-lakidipaud. blogspot.co.id/2014/03/ guru-lakilaki-di-paud.html?m=1) dan menyatakan sebaiknya di PAUD/TK perlu ada guru lakilaki, dengan alasan: 1) Guru laki-laki berperan sebagai guru yang fleksibel dan tidak mengintervensi dan cenderung tidak suka memberikan pelabelan atau stereotipe terhadap gender anak; 2) Guru laki-laki sebagai figure "Ayah" sehingga pada masa usia dini anak-anak tetap memiliki sosok lakilaki yang menjadi figure ayahnya saat berada di sekolah. Selain itu, Guru laki-laki dapat menunjukkan figur sebagai sosok yang positif dalam membentuk identitas maskulinitas pada anak; 3) Guru Laki-laki sebagai sosok lakilaki tradisional. Tsigra menyatakan ada 3 point utama yang menggambarkan pernyataan ini, yaitu: a) guru laki-laki melakukan pekerjaan laki-laki, b) guru laki-laki dapat dengan mudah mengatur dan mendisiplinkan anak karena mereka adalah sosok yang tegas dan bersuara besar (dalam), c) guru laki-laki merupakan figur yang memiliki otoritas atau kekuatan (A Man Of Power).

b. Usia dan Kepangkatan Peserta 
Usia Peserta pada program PkM ini berkisar antara 34 hingga 57 tahun. Hal ini sangat dimaklumi karena pemilihan responden dalam kegiatan ini memiliki persyaratan yaitu mereka yang sudah berada pada jenjang guru PNS senior dengan pangkat paling rendah adalah Peñata Golongan III/c. dan tertinggi Pangkat Pembina golongan IV/a. Oleh karenanya, sangat wajar jika usia peserta berkisar 30 hingga 60 tahun. Berikut adalah grafik penggolongan usia peserta

\section{Usia Responden}

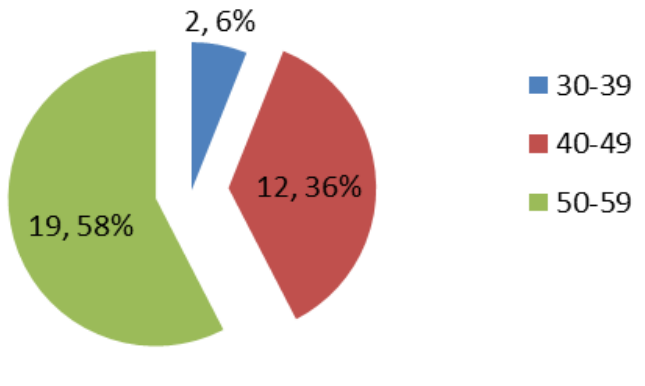

Grafik 2. Penggolongan Usia Peserta

2. Analisis Hasil Asesmen Pengetahuan tentang Penelitian dan Karya Ilmiah

Analisis terkait pengasaan pengetahuan responden tentang penelitian dan karya ilmiah yang diperoleh dari hasil refleksi peserta sendiri melalui instrument yang telah disusun sebelumnya. Instrumen ini diberikan kepada peserta sebelum kegiatan PkM dilaksanakan. Peserta diminta mengisi kuesioner tersebut berdasarkan penilaiannya terhadap dirinya sendiri mengenai pengetahuan dan pemahamannya tentang karya ilmiah dan penelitian. Hasil tersebut kami sebut sebagai pretest. Sedangkan posttest nya kami dapatkan skornya dengan cara memberikan instrument yang sama kepada peserta pada saat kegiatan finalisasi. Artinya pada saat akhir setelah peserta menyelesaikan tugastugasnya dalam menyusun laporan penelitian dankarya ilmiah. Cara mengisinya sama, yaitu peserta diminta merefleksi dirinya sendiri terkait pengetahuan dan pemahamannya terhadap penelitian dan karya ilmiah. Berikut adalah hasil dan analisisnya.
Tabel 10. Hasil Asesmen Pengetahuan tentang Karya Ilmiah

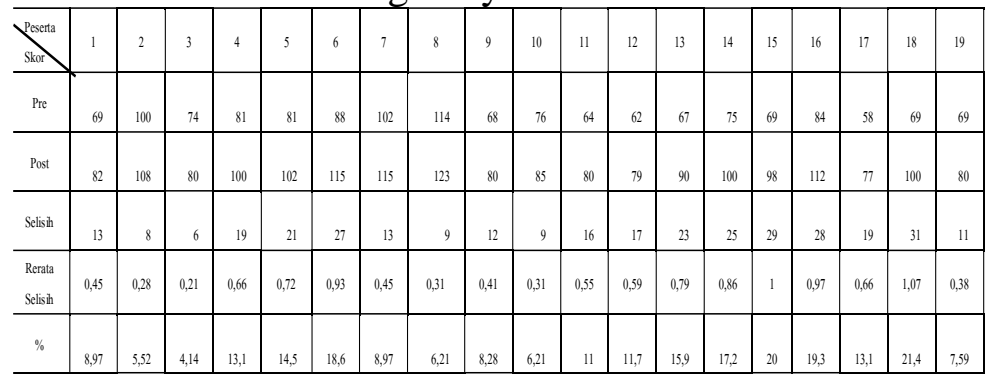

Data tersebut menggambarkan bahwa hampir semua peserta mengalami peningkatan yang cukup signifikan, yaitu sebesar $4,14 \%$ $21,4 \%$. Total skor yang diperoleh merupakan perhitungan dari 29 indikator dengan nilai skor $1-5$.

Besarnya peningkatan terbesar diperoleh oleh peserta nomor 18, sebesar 21, $4 \%$ meskipun total skornya hanya 100 . Hal tersebut menggambarkan bahwa peserta nomor 18 yang semula banyak tidak mengetahui tentang penelitian dan karya ilmiah maka setelah proses pelatihan dilakukan mengalami peningkatan yang cukup besar. Sedangkan peningkatan terendah diperoleh oleh peserta nomor 3 , yaitu hanya sebesar 4,14\% atau sebesar 0,21 point. Meskipun pada awalnya, skor pretest peserta nomor 3 ini tidak terlalu rendah (sebesar 74) namun peningkatannya tidak terlalu banyak, sehingga peserta ini hanya berhasil memiliki poin sebesar 80 atau hanya meningkat sebesar 6 point saja. Artinya, mungkin peserta nomor 3 kurang menyimak dan tidak benar-benar mempelajari penuigasan yang dibarikan dan saat mengerjakan kurang focus.

Skor total pre tes terendah diperoleh oleh peserta nomor 17, yaitu sebesar 58. Peserta ini mengalami kenaikan sebesar 13, $1 \%$ dan meningkat menjadi skor 77 . Berdasarkan hasil ini tampak bahwa peserta nomor 18 mengalami peningkatan yang cukup besar. Meskipun pada awalnya peserta ini memperoleh nilai terendah atau mungkin dianggap tidak banyak yang diketahuinya terkait penelitian dan karya ilmiah namuan pada akhirnya peserta ini berhasil meningkatkan pengetahuannya dan totalnya menjadi 77. Total skor post test ini jika dibandingkan dengan peserta lainnya memang 
tetap berada pada posisi terendah, namun meskipun demikian apresiasi patut diberikan mengingat peserta nomor 18 ini berhasil meningkatkan dirinya sebanyak $13,1 \%$.

Skor total pre test tertinggi diperoleh oleh peserta nomor 7, yaitu sebesar 102 point. Peserta ini mengalami peningkatan sebesar $8,97 \%$ atau meningkat menjadi 115 point. Meskipun pada awalnya peserta ini memiliki skor tertinggi namun jumlah peningkatannya tidaklah terlalu sebsar, yaitu 0,45 point namun peserta ini tetap memiliki nilai tertinggi untuk nilai posttesnya, yaitu sebesar 115 point.

Peserta yang berhasil mendapat nilai tertinggi pada saat posttest juga adalah peserta nomor 6 yaitu dengan total skor 115 point. Peserta ini mengalami peningkatan sebesar $18,6 \%$ dan termasuk dalam 3 (tiga) urutan peningkatan terbesar. Peserta ini berhasil meningkatkan skornya dari 88 point menjadi 115 point atau sebesar 27 point.

Guna memperjelas gambaran adanya peningkatan tiap peserta tersebut, berikut disajikan grafik pendukung. Grafik tersebut hanya menunjukkan adanya peningkatan pada setiap peserta, sedangkan penjelasannya ada dalam penjelasan table 5.5.

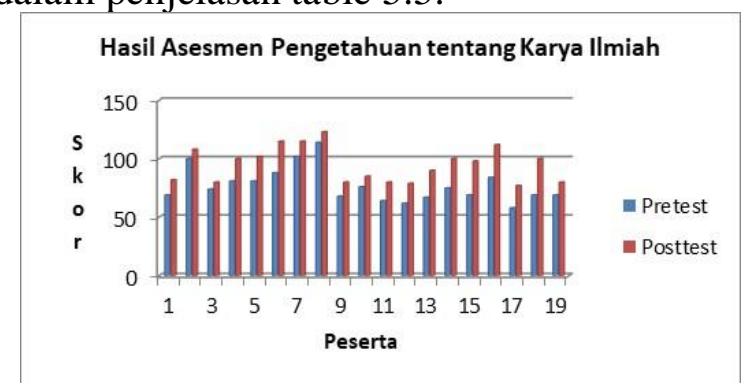

Grafik 3. Total Skor Hasil Asesmen Pengetahuan tentang karya Ilmiah

3. Analisis Hasil Asesmen oleh Pembimbing (Supervisor)

Hasil a asesmen dari Pembimbing atau supervisor merupakan hasil tunggal. Artinya adalah bahwa penilaian oleh pembimbing ini dilakukan hanya sekali selama proses pembimbingan berlangsung. Proses penilaian ini dilakukan oleh Pembimbing melalui observasi ataupun wawancara tidak terstuktur dengan peserta yang dibimbingnya. Berikut adalah skor total penilaian dari Pembimbing tersebut.
Tabel 11. HAsil Asesmen Peserta oleh Pembimbing

\begin{tabular}{|r|r|r|r|r|r|r|r|r|r|r|r|r|r|r|r|r|r|r|r|}
\hline Peserta & 1 & 2 & 3 & 4 & 5 & 6 & 7 & 8 & 9 & 10 & 11 & 12 & 13 & 14 & 15 & 16 & 17 & 18 & 19 \\
\hline Skor & 86 & 88 & 87 & 90 & 103 & 91 & 93 & 102 & 97 & 102 & 96 & 94 & 89 & 98 & 88 & 90 & 103 & 102 & 78 \\
\hline
\end{tabular}

Data tersebut menunjukkan bahwa peserta yang memiliki skor tertinggi adalah Peserta Nomor 5. Peserta ini berdasarkan hasil penilaian pembimbing, mendapatkan skor 5 pada semua indicator, kecuali indicator 8 pada Komponen B, yaitu kemampuan merekam hasil penelitian dan indikator 5 pada komponen A, yaitu datang tepat waktu. Berdasarkan rubriknya, peserta ini berarti membuat rekaman atau catatan selama pelatihan namun tidak lengkap. Peserta ini juga selalu hadir sesuai kesepakatan meskipun satu atau dua kali datang terlambat karena ada hal yang tidak bisa dihindarinya.

Peserta yang memiliki nilai terndah selama proses pembimbingan adalah peserta nomor 19. Peserta ini pada dasarnya sudah cukup rajin dan aktif. Namun dia mendapatkan point 3 pada beberapa indikator, seperti komponen A poin 4, komponen B poin 45 dan komponen $\mathrm{C}$ point 34 .

Pada dasarnya semua peserta cukup aktif dan memenuhi komitmen yang disepakati. Hal ini terlihat bahwa skor yang diperoleh berkisar antara 78-103 artinya berada pada rentang yang cukup tinggi. Karena asumsinya, skor terendah jika guru tidak memiliki komitmet, kesiapan atau tidak berminat maka skornya akan sebesar 23. Sedangkan skor tertinggi yang mungkin dicapai oleh peserta yang memiliki komitmen, kesiapan dan minat yang terbaik adalah 115. Namun demikian ada beberapa peserta yang karena satu dan lain hal terpaksa tidak bisa mencapai penilaian maksimal. Misalnya karena ada kegiatan yang bersamaan pada tanggal kesepakatan, ada kendala dalam berkomunikasi secara online (jaringan kurang lancar, tidak memiliki kuota internet) atau sedang melakukan kegiatan lain seperti Uji Kompetensi Guru (UKG), persiapan Pesta Seni Anak, Lomba Kreativitas Guru sehingga mereka terpaksa tidak merespon saat dihubungi. 


\section{A. KESIMPULAN}

Sebagai tenaga fungsional, guru dituntut untuk terus meningkatkan kemampuan dirinya baik dari sisi pengajaran, penelitian dan publikasi dan pengabdian kepada masyarakat. Poin pengajaran, sudah pasti akan didapatkan karena guru memiliki jam mengajar di sekolah, demikian pula pengabdian kepada masyarakat sudah pasti dilakukan karena guru juga merupakan anggota masyarakat di wilayahnya. Terkait dengan penelitian dan publikasi, banyak guru yang tidak memiliki kesempatan untuk melakukannya karena waktu yang dimilikinya sudah habis untuk urusan mengajar dan abdimas. Oleh karenanya melalui Program PkM yang dilaksanakan oleh Tim UT ini guru-guru khususnya guru TK ditingkatkan kemampuannya dan diberi kesempatan untuk merancang penelitian dan atau menyusun artikel. Hasilnya adalah sebagian besar guru mengalami peningkatan pengetahuannya tentang penelitian dan karya ilmiah. Peningkatan yang terjadi ditunjukkan pada data, yaitu hampir semua peserta mengalami peningkatan yang cukup signifikan, yaitu sebesar 4, $14 \%$ - 21,4\%. Total skor yang diperoleh merupakan perhitungan dari 29 indikator dengan nilai skor $1-5$.

Pada dasarnya semua peserta cukup aktif dan memenuhi komitmen yang disepakati. Hal ini terlihat bahwa skor yang diperoleh berkisar antara 78-103 artinya berada pada rentang yang cukup tinggi. Karena asumsinya, skor terendah jika guru tidak memiliki komitmet, kesiapan atau tidak berminat maka skornya akan sebesar 23. Sedangkan skor tertinggi yang mungkin dicapai oleh peserta yang memiliki komitmen, kesiapan dan minat yang terbaik adalah 115. Namun demikian ada beberapa peserta yang karena satu dan lain hal terpaksa tidak bisa mencapai penilaian maksimal. Misalnya karena ada kegiatan yang bersamaan pada tanggal kesepakatan, ada kendala dalam berkomunikasi secara online (jaringan kurang lancar, tidak memiliki kuota internet) atau sedang melakukan kegiatan lain seperti Uji Kompetensi Guru (UKG), persiapan Pesta Seni Anak, Lomba Kreativitas Guru sehingga mereka terpaksa tidak merespon saat dihubungi.

\section{B. SARAN}

Berdasarkan hasil penelitian ini, agar program PkM ini dilanjutkan pada guru-guru yang lainnya dari jenjang TK/RA hingga SMA sederajat karena pelatihan semacam ini sangat bermanfaat dan membantu para guru untuk bisa meningkatkan kemampuan dan pengetahuannya dalam keterampilan menulis karya ilmiah dan melakukan penelitian.

\section{DAFTAR PUSTAKA}

Ary, et.al, (1982).Pengantar penelitian dalam Pendidikan .terjemahan Arief Furchan. Surabaya : Usaha Nasional.

Arief Furchan, (1982). Pengantar Penelitian dalam Pendidikan (Surabaya: Usaha Nasional.

Theresia Alviani Sum dan Adriani Tamo Ina Talu. (2018). Faktor Penyebab Kurangnya Minat Laki-Laki Untuk Menjadi Guru Paud Di Kabupaten Manggarai. Jurnal Pendidikan dan Kebudayaan Missio, Volume 10, Nomor 2, Juni 2018.

Meni Tsigra. (2014). Male Teacher and Children Gender Construction In Preschool dalam (http://peranguru-laki-laki-dipaud. blogspot.co.id/2014/03/guru-laki-laki-di-paud. html?m=1),

http://referensi.data.kemdikbud.go.id/index 21 . php

http://www.dedihariyadi.web.id/2017/04/daft ar-penerima-tunjangan-profesipns.html 